\title{
Characterization of the variability and repeatability of gonadotropin- releasing hormone-induced luteinizing hormone responses in dairy cows within a synchronized ovulation protocol
}

\author{
M. Gobikrushanth, ${ }^{*}$ P. A. Dutra, ${ }^{*}$ T. C. Bruinjé, ${ }^{*}$ M. G. Colazo,† S. T. Butler,ł and D. J. Ambrose ${ }^{*} \dagger^{1}$ \\ *Department of Agricultural Food and Nutritional Science, University of Alberta, Edmonton, AB, T6G 2P5 Canada \\ †Livestock Research and Extension Branch, Alberta Agriculture and Forestry, Edmonton, AB, T6H 5T6 Canada \\ ¥Teagasc, Animal and Grassland Research and Innovation Centre, Moorepark, Fermoy, Co. Cork, Ireland
}

\begin{abstract}
The primary objective was to determine the variability and repeatability of $\mathrm{GnRH}$-induced LH responses. The secondary objective was to evaluate the associations among plasma LH, FSH, estradiol (E2), and progesterone (P4) concentrations. One hundred lactating Holstein cows (35 primiparous, 65 multiparous) were initially subjected to a presynchronization protocol $(\mathrm{d}$ $0, \mathrm{PGF}_{2 \alpha} ; \mathrm{d} 3, \mathrm{GnRH}$ ) followed $7 \mathrm{~d}$ later by Ovsynch (d 10, GnRH; d 17, $\mathrm{PGF}_{2 \alpha} ; 56 \mathrm{~h}$ later, $\mathrm{GnRH}$ ) and timed artificial insemination $16 \mathrm{~h}$ after the last GnRH. Blood samples were collected immediately before the GnRH injection of presynchronization and the second GnRH of Ovsynch to determine plasma concentrations of LH, FSH, and P4. A second blood sample was collected $2 \mathrm{~h}$ after each of the above GnRH injections to determine GnRH-induced LH and FSH concentrations. Plasma concentrations of E2 were also determined in samples collected immediately before the second $\mathrm{GnRH}$ of Ovsynch. Cows that (1) had higher LH concentrations at $0 \mathrm{~h}$ than at $2 \mathrm{~h}$ after GnRH, (2) showed an ongoing spontaneous LH surge, (3) did not respond to $\mathrm{GnRH}$, and (4) had $\mathrm{P} 4 \geq 0.5 \mathrm{ng} / \mathrm{mL}$ at $\mathrm{GnRH}$ of presynchronization and the second GnRH of Ovsynch were excluded from the analysis. The variability (coefficient of variation) and repeatability [between animal variance/(within animal variance + between animal variance)] of GnRH-induced LH response were determined from samples collected $2 \mathrm{~h}$ after the $\mathrm{GnRH}$ of presynchronization and the second GnRH of Ovsynch. The associations among plasma LH, FSH, E2, and $\mathrm{P} 4$ were determined at the second GnRH of Ovsynch. Mean $( \pm$ SEM) LH concentrations before GnRH were $0.5 \pm 0.04$ and $0.6 \pm 0.03 \mathrm{ng} / \mathrm{mL}$, whereas mean $\mathrm{LH}$
\end{abstract}

Received December 28, 2016.

Accepted April 6, 2017.

${ }^{1}$ Corresponding author: divakar.ambrose@gov.ab.ca concentrations $2 \mathrm{~h}$ after $\mathrm{GnRH}$ were $9.8 \pm 1.0$ and $12.1 \pm 0.8 \mathrm{ng} / \mathrm{mL}$ at $\mathrm{GnRH}$ of presynchronization and the second GnRH of Ovsynch, respectively. The variability of GnRH-induced LH was 76.1 and $52.1 \%$ at $\mathrm{GnRH}$ of presynchronization and the second $\mathrm{GnRH}$ of Ovsynch, respectively. The repeatability estimate for GnRH-induced LH concentration between GnRH of presynchronization and Ovsynch assessments was 0.10. Plasma concentrations of LH were positively associated with FSH and E2 ( $\mathrm{r}=0.61$ and 0.30 , respectively) and negatively associated with $\mathrm{P} 4(\mathrm{r}=-0.46)$ at the second GnRH of Ovsynch. In summary, GnRH-induced LH responses were highly variable and unrepeatable, and LH concentrations were positively associated with FSH and E2 and negatively associated with P4.

Key words: luteinizing hormone, variability, repeatability, progesterone

\section{INTRODUCTION}

A functional hypothalamic-pituitary-gonadal axis is essential for regulation of reproduction in both male and female mammals (Land, 1973). Gonadotropinreleasing hormone is a decapeptide synthesized and released by GnRH neurons in the hypothalamus that induces the release of FSH and LH from the anterior pituitary gland through receptor-mediated mechanisms (Kaltenbach et al., 1974; Fink, 1988). Progesterone (P4) and estradiol (E2) regulate FSH and LH release through positive and negative feedback mechanisms that act on the hypothalamus, anterior pituitary, or both (Goodman and Karsch, 1980; Karsch, 1987; Nett et al., 2002). Whereas FSH is required for follicular wave emergence (Adams et al., 1992), LH is essential for dominant follicle growth (Ginther, 2000), oocyte maturation (Hyttel et al., 1989), ovulation, corpus luteum development, and synthesis of P4 (Tomac et al., 2011). These events are critical for establishment and maintenance of pregnancy in domestic animals (Spencer et al., 2004). Therefore, selecting cows with greater 
capacity for LH secretion under defined conditions could be a strategy to improve fertility in dairy cows.

A phenotype that has high variability, repeatability, and heritability would be an ideal candidate for genetic selection. The variability and repeatability of other novel fertility traits such as anti-Müllerian hormone and antral follicle count (Burns et al., 2005; Ireland et al., 2008; Gobikrushanth et al., 2017) and their association with fertility outcomes have been of recent interest to many researchers (Mossa et al., 2012; Ribeiro et al., 2014). However, the variability, repeatability, and association with fertility under minimal influence of $\mathrm{P} 4$ have not been examined for $\mathrm{GnRH}$-induced $\mathrm{LH}$ responses in dairy cows. Previous studies in rams and ewes (Haley et al., 1989) and beef cows (Webb et al., 1977; Williams et al., 1982; Williams and Stanko 1996; Fajersson et al., 1999) reported that GnRH-induced LH responses were variable between animals based on simple observations. However, none of the above studies quantified the variability with statistical analysis or were specific to lactating dairy cows. Endogenous LH release is pulsatile, resulting in a low correlation between repeated measures from the same animal (Haley et al., 1989); furthermore, measuring endogenous LH surge in large populations is impractical, making it an undesirable candidate trait for genetic selection. However, the induced LH surge response after exogenous GnRH administration may be a more useful endocrine parameter for investigating variability and repeatability. Previous studies reported a poor and nonsignificant repeatability for GnRH-induced LH responses when ram and ewe lambs (Tyrrell et al., 1980; $\mathrm{n}=15$ for each sex) and beef cows (Fajersson et al., 1999; $\mathrm{n}=18$ ) were repeatedly challenged with exogenous GnRH treatments. However, small sample sizes and variable concentrations of $\mathrm{P} 4$ might have contributed to nonsignificant repeatability estimates. In addition, although high heritability $\left(\mathrm{h}^{2}=\right.$ 0.44) and associations between high LH concentrations and fecundity have been reported in ewes, the associations were inconsistent (Haley et al., 1989). Similar conceptual studies evaluating the association between GnRH-induced LH responses and fertility in lactating dairy cows are lacking.

Evaluating the variability and repeatability of GnRHinduced LH response and establishing its association with fertility may identify it as a fertility phenotype to be considered in future genomic selection in dairy cows. We hypothesized that cows have variable responses to GnRH injection even under low P4 environment and those responses are repeatable. Therefore, our primary objective was to determine the variability and repeatability of GnRH-induced LH responses. The secondary objective was to evaluate the associations among plasma LH, FSH, E2, and P4 concentrations. In addition, the associations among LH response categories, FSH, E2, P4, and reproductive outcomes [i.e., ovulatory response, pregnancies per AI (P/AI), pregnancy at $60 \mathrm{~d}$ after AI and pregnancy loss] were also examined.

\section{MATERIALS AND METHODS}

\section{Animals and Housing}

The study was conducted at the Dairy Research and Technology Centre of the University of Alberta between November 2014 and September 2016. All the experimental procedures were approved by the University of Alberta's Animal Care and Use Committee for Livestock, and animals were cared for in accordance with the requirements of Canadian Council on Animal Care (2009). One hundred lactating Holstein cows (35 primiparous, 65 multiparous) were initially enrolled in the study. Cows were individually fed a total mixed ration (primary ingredients were barley silage, alfalfa silage, alfalfa hay, and concentrates) and housed in tie-stalls and let out for approximately $2 \mathrm{~h}$ of exercise during weekdays. Diets were formulated according to NRC (2001) to meet the requirements of a $650-\mathrm{kg}$ lactating cow producing $45 \mathrm{~kg}$ of milk/d, and cows had ad libitum access to water.

\section{Reproductive Management and Blood Sampling}

Cows that were on average $52(\mathrm{SD}=4.0$; range $=$ 45 to 59) DIM were placed on a modified G6G protocol and subjected to timed AI (Figure 1). In brief, the presynchronization protocol consisted of $\mathrm{PGF}_{2 \alpha}(\mathrm{d}$ 0; Estrumate, 500 g, i.m; Merck Intervet Corp., Kirkland, QC, Canada) and GnRH (d 3; Fertiline; $100 \mu \mathrm{g}$ of gonadorelin acetate, i.m.; Vetoquinol N. A. Inc. Lavaltrie QC, Canada) administered $3 \mathrm{~d}$ apart. The Ovsynch protocol was initiated $7 \mathrm{~d}$ after the GnRH injection of the presynchronization program and involved i.m. injections of GnRH (d 10), $\mathrm{PGF}_{2 \alpha}$ (d 17), and GnRH $56 \mathrm{~h}$ later, followed by timed AI 16 to $20 \mathrm{~h}$ later (mean DIM $=72$ ).

Transrectal ultrasonography (Aloka 500, Aloka Co Ltd., Tokyo, Japan) using a 7.5-MHz linear array transducer was first conducted at the time of the second GnRH of Ovsynch ( $\sim 71$ DIM) to confirm the presence of one or more putative ovulatory follicles $(\geq 10 \mathrm{~mm}$ in diameter). Ovulation was confirmed on 73 DIM by the absence of the follicles that had been detected at the previous ultrasound examination. Ovulatory response was defined as the proportion of cows that ovulated after the second GnRH of Ovsynch. Transrectal ultrasonography of uterine contents was performed $33 \mathrm{~d}$ after $\mathrm{AI}$ and visualization of a viable embryo confirmed the 


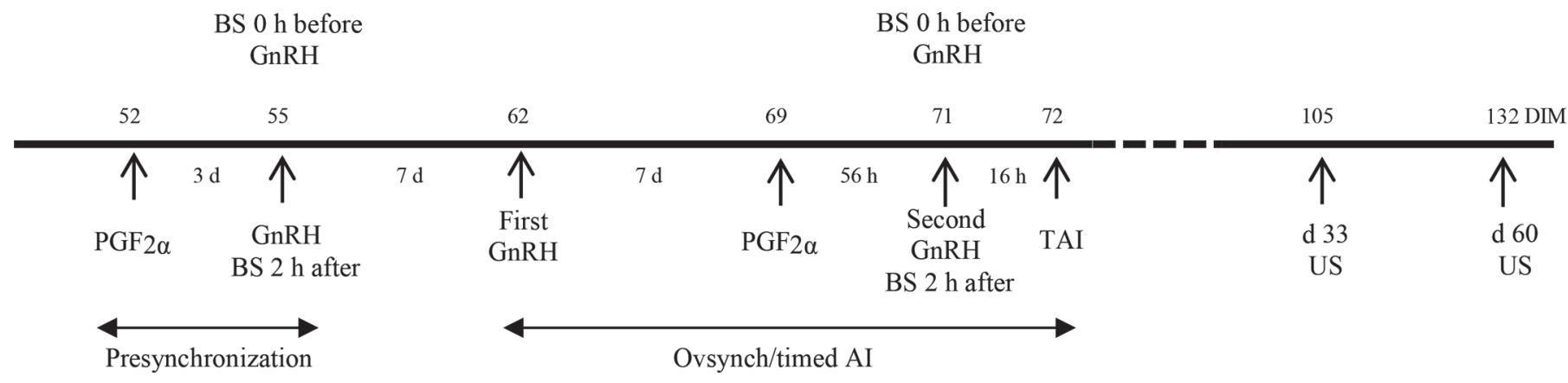

Figure 1. One hundred lactating Holstein cows (35 primiparous, 65 multiparous) were subjected to a modified presynchronization-Ovsynch

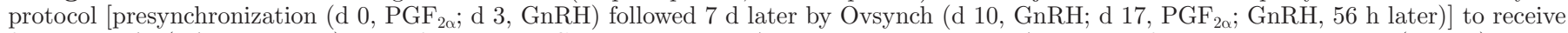
first timed AI (TAI; $\sim 72 \mathrm{DIM}) 16 \mathrm{~h}$ after the last GnRH treatment. All injections and timed-AI were performed in the morning (0800 h) except for the second $\mathrm{GnRH}$ of Ovsynch, which was given in the afternoon $(1600 \mathrm{~h})$. Blood samples (BS) were collected immediately before $(0 \mathrm{~h})$ the $\mathrm{GnRH}$ of presynchronization and the second GnRH of Ovsynch to determine plasma concentrations of LH, FSH, and progesterone (P4, ng/ $\mathrm{mL}$ ), and $2 \mathrm{~h}$ after each of the above $\mathrm{GnRH}$ injections to determine plasma $\mathrm{LH}$ and FSH $(\mathrm{ng} / \mathrm{mL})$. Plasma concentrations of estradiol (E2) were determined from BS collected immediately before the second GnRH of Ovsynch. Transrectal ultrasonography (US) was first conducted at the time of the second GnRH of Ovsynch ( 71 DIM) to confirm presence of putative ovulatory follicle(s). Ovulation was confirmed on 73 DIM by the absence of follicle(s) ( $\geq 10 \mathrm{~mm}$ in diameter) that had been detected at the previous US examination (not illustrated). Pregnancy was diagnosed at $33 \mathrm{~d}$ after AI by US, and cows diagnosed pregnant were reconfirmed at $60 \mathrm{~d}$ after AI by US.

pregnancy. Cows that were determined pregnant at 33 $\mathrm{d}$ after AI were examined again at $60 \mathrm{~d}$ after AI using transrectal ultrasonography to reconfirm pregnancy. Pregnancies per AI at $33 \mathrm{~d}$ and pregnancy at $60 \mathrm{~d}$ after AI were determined based on the proportion of cows pregnant at 33 and $60 \mathrm{~d}$ after AI, respectively. When embryonic death occurred between 33 and $60 \mathrm{~d}$ after AI, it was considered as a pregnancy loss.

Blood samples were collected from coccygeal blood vessel using evacuated Vacutainer tubes containing sodium heparin as an anticoagulant (Becton Dickinson and Company, Franklin Lakes, NJ) immediately before $(0 \mathrm{~h})$ the $\mathrm{GnRH}$ of presynchronization and the second GnRH of Ovsynch to determine plasma concentrations of $\mathrm{LH}, \mathrm{FSH}$, and $\mathrm{P} 4(\mathrm{ng} / \mathrm{mL})$ and $2 \mathrm{~h}$ after each of the above $\mathrm{GnRH}$ treatments to determine plasma $\mathrm{LH}$ and FSH $(\mathrm{ng} / \mathrm{mL})$. The 2-h interval for collecting blood samples after GnRH administration to determine maximum pituitary responsiveness to GnRH was based on LH profiles in previous studies (Ambrose et al., 2005; Colazo et al., 2009; Dias et al., 2010; Pulley et al., 2015). Plasma concentrations of E2 were determined from blood samples collected immediately before the second GnRH of Ovsynch. Samples were placed on ice upon collection and centrifuged at $1,500 \times g$ for $20 \mathrm{~min}$ at $4^{\circ} \mathrm{C}$, and plasma harvested and frozen at $-20^{\circ} \mathrm{C}$ until assayed for plasma LH, FSH, E2, and P4.

\section{Determination of Plasma Concentrations of, FSH, E2, and P4}

Plasma concentrations of LH, FSH, E2, and P4 were determined at Endocrine Lab Services, University of Saskatchewan, Saskatoon, SK, Canada.
Plasma LH concentrations were determined in duplicate using a double-antibody RIA (NIDDK-bLH4) as described by Evans et al. (1994). All samples were analyzed in a single assay; the intraassay coefficient of variation $(\mathbf{C V})$ was $12.3 \%$ for low reference samples (mean, $0.98 \mathrm{ng} / \mathrm{mL}$ ) and $9.2 \%$ for high reference samples (mean, $1.70 \mathrm{ng} / \mathrm{mL}$ ).

Plasma FSH concentrations were determined in duplicate using a double-antibody RIA using NIDDKanti-oFSH-1 primary antibody and expressed as USDA bovine FSH-Il units as described by Evans et al. (1994). All samples were analyzed in a single assay; the intraassay CV was $10.1 \%$ for low reference samples (mean, $0.27 \mathrm{ng} / \mathrm{mL}$ ) and $4.5 \%$ for high reference samples (mean, $3.17 \mathrm{ng} / \mathrm{mL}$ )

Plasma concentrations of E2 were determined after ether extraction using a RIA procedure as originally described by Rawlings et al. (1984). All samples were analyzed in a single assay; the intraassay CV was $13.7 \%$ for low reference samples (mean, $2.8 \mathrm{pg} / \mathrm{mL}$ ) and $12.1 \%$ for high reference samples (mean, $9.1 \mathrm{pg} / \mathrm{mL}$ ).

Plasma P4 concentrations were determined in duplicate using a commercial solid-phase RIA kit (ImmuChem; MP Biomedicals, LLC, Orangeburg, NY). All samples were analyzed in a single assay. The intraassay CV were $18.6 \%$ for low (mean, $1.2 \mathrm{ng} / \mathrm{mL}$ ) and $11.6 \%$ for high reference samples (mean, $10.8 \mathrm{ng} / \mathrm{mL}$ ), respectively.

\section{Statistical Analysis}

Data were analyzed using SAS version 9.4 (SAS Institute Inc., Cary, NC). Cows that fell within the following criteria were excluded from the analysis: (1) LH 
concentrations were greater at $0 \mathrm{~h}$ than at $2 \mathrm{~h}$ after $\mathrm{GnRH}(\mathrm{n}=0$ at $\mathrm{GnRH}$ of presynchronization; $\mathrm{n}=2$ at the second GnRH of Ovsynch); (2) LH concentrations were indicative of an ongoing spontaneous LH surge at $0 \mathrm{~h}(\geq 1.0 \mathrm{ng} / \mathrm{mL})$ even if $\mathrm{LH}$ concentration increased further at $2 \mathrm{~h}$ after $\mathrm{GnRH}$ injection $(\mathrm{n}=7$ at $\mathrm{GnRH}$ of presynchronization; $\mathrm{n}=3$ at the second $\mathrm{GnRH}$ of Ovsynch); and (3) did not exhibit an increase in plasma LH in response to $\mathrm{GnRH}$ administration ( $\mathrm{n}=$ 4 at $\mathrm{GnRH}$ of presynchronization; $\mathrm{n}=4$ at the second GnRH of Ovsynch). A GnRH-induced LH response was considered to have occurred when the LH concentration at $2 \mathrm{~h}$ after $\mathrm{GnRH}$ exceeded the mean of the baseline by 2 standard deviations (Pulley et al., 2015).

The mean, standard error of mean (SEM), range, and coefficient of variation (variability) for $\mathrm{GnRH}$-induced LH were first determined in 89 cows at GnRH of presynchronization and 91 cows at the second $\mathrm{GnRH}$ of Ovsynch using MEANS procedure of SAS and later determined in cows that had plasma $\mathrm{P} 4<0.5 \mathrm{ng} / \mathrm{mL}$ at GnRH of presynchronization $(\mathrm{n}=60)$ and the second GnRH of Ovsynch $(\mathrm{n}=70)$. The cutoff of $<0.5 \mathrm{ng} /$ $\mathrm{mL}$ was chosen to simulate concentrations of P4 during estrus as suggested by Stevenson and Pulley (2016). In addition, this $\mathrm{P} 4$ concentration was the optimum to predict the probability of pregnancy using receiver operating characteristic analysis in the current study (sensitivity $94.4 \%$ and specificity $27.4 \%$ ) and in previous studies (Wilsdorf et al., 2016; Colazo et al., 2017).

The repeatability (range 0 to 1 , with 1 being the highest) was defined as the proportion of the total variance that attributed to between-animal variance, which was calculated as $\sigma^{2}$ between-animal $/\left(\sigma^{2}\right.$ between-animal + $\sigma^{2}$ within-animal). Variance components were estimated using ANOVA in Excel 2016 (Microsoft, Redmond, WA), and the repeatability for GnRH-induced LH responses between GnRH of presynchronization and the second GnRH of Ovsynch was calculated. Furthermore, the association between $\mathrm{GnRH}$ of presynchronization and the second GnRH of Ovsynch assessments for GnRH-induced LH response was determined by estimating the Pearson correlation of coefficient (r; ranges from -1 to +1 , where values $0,<0$, and $>0$ indicate no association, negative association, and a positive association, respectively) using CORR procedure of SAS. These analyses were conducted first in all 81 cows and later in a subset of cows $(\mathrm{n}=45)$ that had plasma $\mathrm{P} 4$ concentrations $<0.5 \mathrm{ng} / \mathrm{mL}$ at both assessments.

The associations among plasma LH, FSH, E2, and $\mathrm{P} 4$ were determined first in all 91 cows and later in a subset of 70 cows that had $\mathrm{P} 4<0.5 \mathrm{ng} / \mathrm{mL}$ at the second GnRH of Ovsynch by estimating the Pearson correlation of coefficient using CORR procedure of SAS. Moreover, the linear regression among the afore- mentioned continuous variables was also tested using REG procedure of SAS and the regression line and equation were plotted using Excel 2016.

Cows that had P4 concentration $<0.5 \mathrm{ng} / \mathrm{mL}$ at the second GnRH of Ovsynch $(\mathrm{n}=70)$ were ranked based on plasma LH, from highest to lowest, and those in the top $(\mathrm{n}=24)$ and bottom $(\mathrm{n}=24)$ thirds were classified into high- and low-LH categories. The associations among LH categories, parity, and plasma concentrations of FSH, E2, and P4 were determined using MIXED procedure SAS. The associations among $\mathrm{LH}$ response categories, parity, ovulatory response to the second GnRH of Ovsynch, P/AI at $33 \mathrm{~d}$ after $\mathrm{AI}$, pregnancy at $60 \mathrm{~d}$ after $\mathrm{AI}$, and pregnancy loss were tested using GLIMMIX procedure of SAS. The aforementioned continuous and binomial variables were initially modeled against LH category, parity, and their interactions. Because none of the interactions was significant, the final model only included LH category and parity. Significant differences were reported if $P \leq 0.05$ and considered to be a tendency if $P>0.05$ and $\leq 0.10$.

\section{RESULTS}

\section{Variability and Repeatability of GnRH-Induced Release of $\mathrm{LH}$}

Mean $( \pm$ SEM) plasma concentrations of LH before the $\mathrm{GnRH}$ of presynchronization $(0.4 \pm 0.03 \mathrm{ng} / \mathrm{mL})$ did not differ $(P>0.05)$ from those preceding the second $\mathrm{GnRH}$ of Ovsynch $(0.6 \pm 0.03 \mathrm{ng} / \mathrm{mL})$. Likewise, $\mathrm{LH}$ concentrations $2 \mathrm{~h}$ after $\mathrm{GnRH}$ of presynchronization $(8.7 \pm 0.7$; range $=1.2$ to $27.4 \mathrm{ng} / \mathrm{mL})$ and Ovsynch $(10.4 \pm 0.7$; range $=1.2$ to $28.4 \mathrm{ng} / \mathrm{mL})$ did not differ $(P>0.05)$. The variability of the $\mathrm{GnRH}$ induced LH response was 78.7 and $63.1 \%$ at $\mathrm{GnRH}$ of presynchronization and the second $\mathrm{GnRH}$ of Ovsynch assessments, respectively. When evaluated in cows that had $\mathrm{P} 4<0.5 \mathrm{ng} / \mathrm{mL}$, the variability values were 76.1 and $52.1 \%$ at $\mathrm{GnRH}$ of presynchronization and the second GnRH of Ovsynch assessments, and the mean $( \pm$ SEM $)$ LH $2 \mathrm{~h}$ after GnRH did not differ $(P>0.05)$ between presynchronization and Ovsynch assessments and were $9.8 \pm 1.0$ (range, 1.4 to $27.4 \mathrm{ng} / \mathrm{mL}$ ) and $12.1 \pm 0.8$ (range, 1.2 to $28.4 \mathrm{ng} / \mathrm{mL}$ ) at $\mathrm{GnRH}$ of presynchronization $(\mathrm{n}=60)$ and the second $\mathrm{GnRH}$ of Ovsynch ( $\mathrm{n}=70$; Figure $2 \mathrm{a}, \mathrm{b})$. The repeatability of GnRH-induced LH concentrations between presynchronization and Ovsynch assessments was low (0.16) yet significant when determined in all cows $(\mathrm{n}=81 ; P=$ 0.02 ) and repeatability (0.10) was nonsignificant when determined only in cows that had $\mathrm{P} 4<0.5 \mathrm{ng} / \mathrm{mL}$ (n $=45 ; P=0.25)$. The estimated correlation coefficient for $\mathrm{GnRH}$-induced LH between presynchronization and 


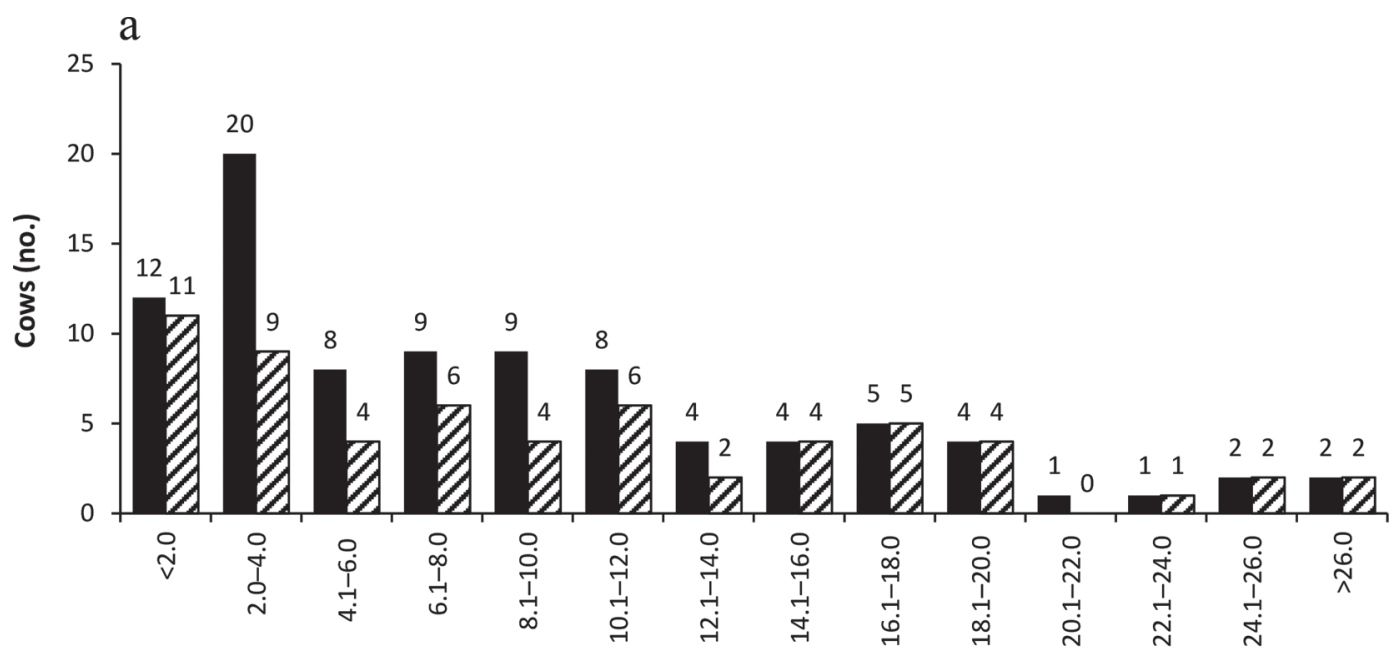

Plasma LH $(\mathrm{ng} / \mathrm{mL})$ at $2 \mathrm{~h}$ after the $\mathrm{GnRH}$ of presynchronization

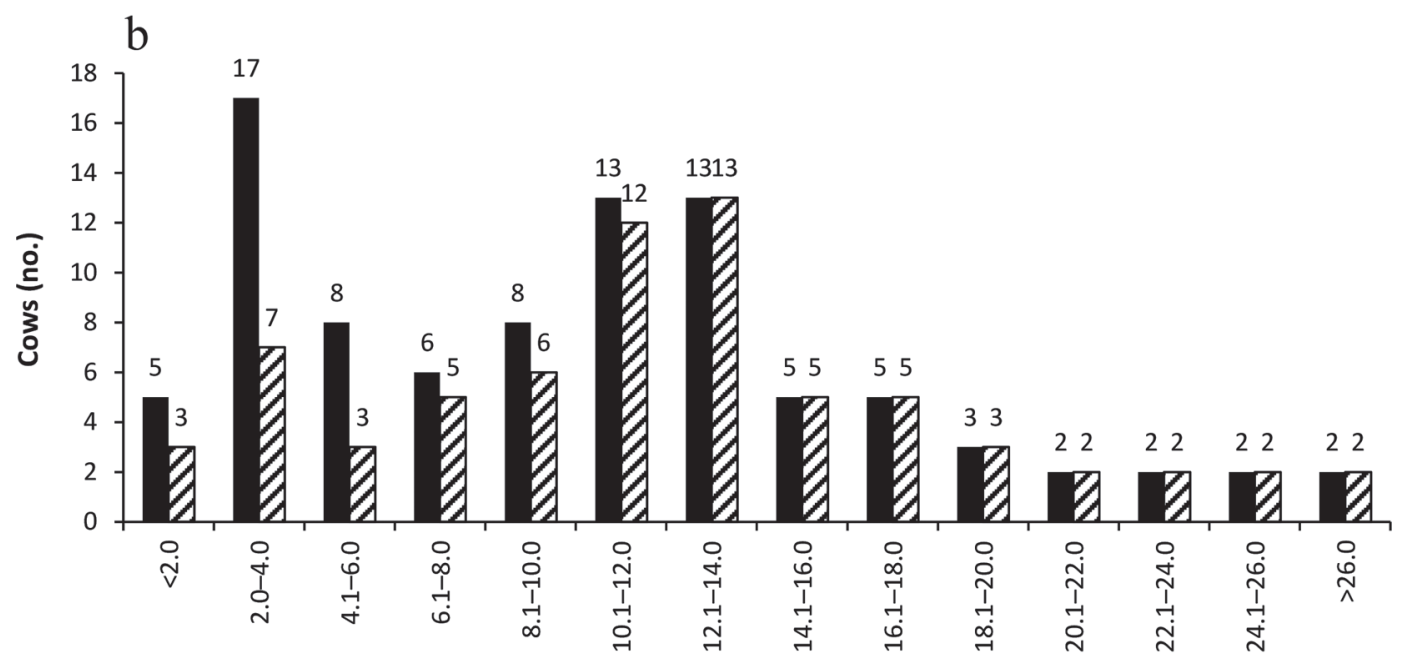

Plasma LH $(\mathrm{ng} / \mathrm{mL})$ at $\mathbf{2} \mathrm{h}$ after the second $\mathrm{GnRH}$ of Ovsynch

Figure 2. The distribution of plasma LH concentrations $(\mathrm{ng} / \mathrm{mL})$ determined at $2 \mathrm{~h}$ after the GnRH of presynchronization (a) and the second GnRH of Ovsynch (b) in all cows (solid bars; $\mathrm{n}=89$ for presynchronization and 91 for Ovsynch assessments) and in cows that had plasma progesterone $(\mathrm{P} 4)<0.5 \mathrm{ng} / \mathrm{mL}$ (hatched bars; $\mathrm{n}=60$ for presynchronization and 70 for Ovsynch assessments).

Ovsynch assessments was $0.24(P=0.03)$ when evaluated in all cows $(\mathrm{n}=81$; Figure $3 \mathrm{a})$ and $0.15(P=0.33)$ when evaluated only in cows that had $\mathrm{P} 4<0.5 \mathrm{ng} / \mathrm{mL}$ $(\mathrm{n}=45 ;$ Figure $3 \mathrm{~b})$.

\section{Associations Among Plasma LH Concentrations and $\mathrm{FSH}, \mathrm{E2}$, and $\mathrm{P4}$}

Plasma concentrations of LH were positively associated with FSH $(\mathrm{r}=0.65 ; P<0.01$; Figure $4 \mathrm{a})$ and E2 $(\mathrm{r}=0.35 ; P<0.01 ;$ Figure $5 \mathrm{a})$ in all 91 cows as well as in the 70 cows that had $\mathrm{P} 4<0.5 \mathrm{ng} / \mathrm{mL}$ at the second GnRH of Ovsynch $(\mathrm{r}=0.61$ and $0.30 ; P<0.01$; Figure $4 \mathrm{~b}$ and $5 \mathrm{~b}$, respectively). On the other hand, LH concentrations had a negative association with $\mathrm{P} 4$ when evaluated in all 91 cows $(\mathrm{r}=-0.45 ; P<0.01$; Figure $6 a)$ as well as in cows that had $\mathrm{P} 4 \geq 0.5 \mathrm{ng} / \mathrm{mL}(\mathrm{r}=$ $-0.46 ; P=0.03$; Figure 6b). However, the association was very poor and nonsignificant in cows that had $\mathrm{P} 4$ $<0.5 \mathrm{ng} / \mathrm{mL}(\mathrm{r}=-0.07 ; P=0.54 ;$ Figure $6 \mathrm{c})$.

\section{Associations Among LH Categories, Parity, Plasma Hormones, and Reproductive Outcomes}

Cows that were categorized as high-LH had greater $(P<0.01)$ mean plasma concentrations of FSH and a tendency $(P=0.09)$ for higher E2 than those categorized as low-LH, but plasma $\mathrm{P} 4$ and the reproductive outcomes evaluated did not differ between high-LH and low-LH categories (Table 1). 
Primiparous cows had a tendency for lower P4 (mean $\pm \mathrm{SEM} ; 0.001 \pm 0.01$ vs. $0.03 \pm 0.01 \mathrm{ng} / \mathrm{mL} ; P=0.06)$ and greater $\mathrm{P} / \mathrm{AI}$ at $33 \mathrm{~d}$ after $\mathrm{AI}$ (60.0 vs. $32.1 \%$; $P=0.06)$ than multiparous cows. However, mean plasma concentrations of LH, FSH, and E2, and other reproductive outcomes (i.e., pregnancy at $60 \mathrm{~d}$ after AI, ovulatory response and pregnancy loss) did not differ between primiparous and multiparous cows (Table 1).

\section{DISCUSSION}

The variability for GnRH-induced LH responses was high at both presynchronization and Ovsynch assessments. To the best of our knowledge, this study is the first to report variability of $\mathrm{GnRH}$-induced $\mathrm{LH}$ responses under minimal influences of $\mathrm{P} 4$ in lactating dairy cows. Progesterone had a negative association with LH response in the current study (Figure 6a, b), which has also been reported in previous studies (Colazo et al., 2008; Giordano et al., 2012; Stevenson and Pulley, 2016). Elevated circulating P4 affects LH through several mechanisms: direct inhibition of $\mathrm{LH}$
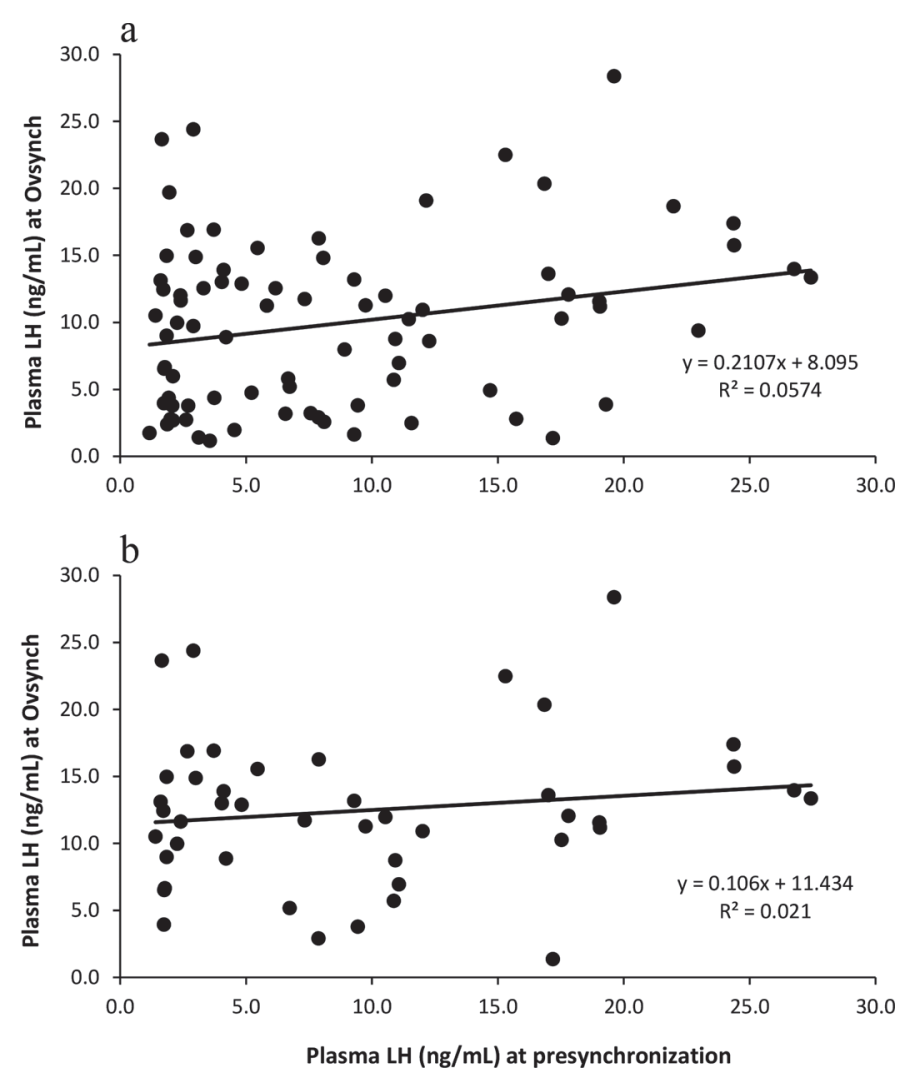

Figure 3. Association between plasma $\mathrm{LH}(\mathrm{ng} / \mathrm{mL})$ determined at $2 \mathrm{~h}$ after $\mathrm{GnRH}$ of presynchronization and the second $\mathrm{GnRH}$ of Ovsynch in all cows (a; $\mathrm{n}=81 ; P=0.03)$ and in cows that had progesterone (P4) concentrations $<0.5 \mathrm{ng} / \mathrm{mL}$ at both $\mathrm{GnRH}$ of presynchronization and at the second $\mathrm{GnRH}$ of Ovsynch ( $\mathrm{b} ; \mathrm{n}=45 ; P=0.33$ )
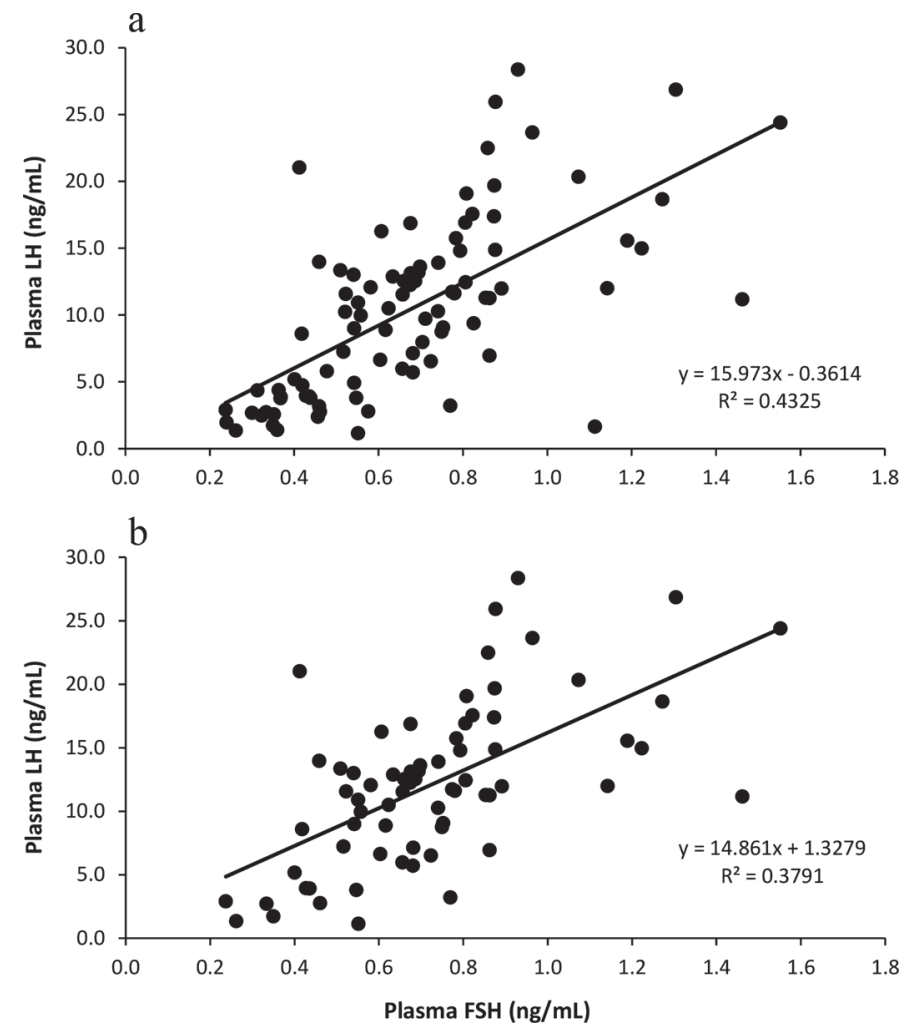

Figure 4. Association between plasma FSH and LH $(\mathrm{ng} / \mathrm{mL})$ determined at $2 \mathrm{~h}$ after the second GnRH of Ovsynch in all cows $(\mathrm{a} ; \mathrm{n}=$ $91 ; P<0.01)$ and in cows that had progesterone $(\mathrm{P} 4)<0.5 \mathrm{ng} / \mathrm{mL}$ at the second GnRH of Ovsynch (b; $\mathrm{n}=70 ; P<0.01$ )

release from the anterior pituitary gland (Schoenemann et al., 1985), down-regulation of $\mathrm{GnRH}$ receptors in the pituitary gland, thereby reducing pituitary responsiveness to GnRH, and through inhibition of GnRH pulses from the hypothalamus (Nett et al., 2002). Therefore, we inferred that the high variability values observed for $\mathrm{GnRH}$-induced LH responses (78.7 and $63.1 \%$ at presynchronization and Ovsynch assessments, respectively) were negatively influenced by peripheral P4 concentrations at the time of GnRH administration. Notably, the between-animal variability values were decreased, yet remained high (76.1 and $52.1 \%$ at presynchronization and Ovsynch assessments, respectively) despite adjusting for the possible suppressive influence of $\mathrm{P} 4$ on $\mathrm{LH}$, by removing cows with $\mathrm{P} 4 \geq 0.5 \mathrm{ng} / \mathrm{mL}$, indicating that a wide phenotypic variation exists for GnRH-induced LH responses in dairy cows, even after accounting for the possible effects of $\mathrm{P} 4$.

The repeatability of GnRH-induced LH concentration between presynchronization and Ovsynch assessments was low $(0.16)$ when evaluated in all cows $(P=0.02)$. Our finding is in agreement with previous reports in small (Tyrrell et al., 1980) and large ruminants (Fajersson et al., 1999). Tyrrell et al. (1980) reported poor and 

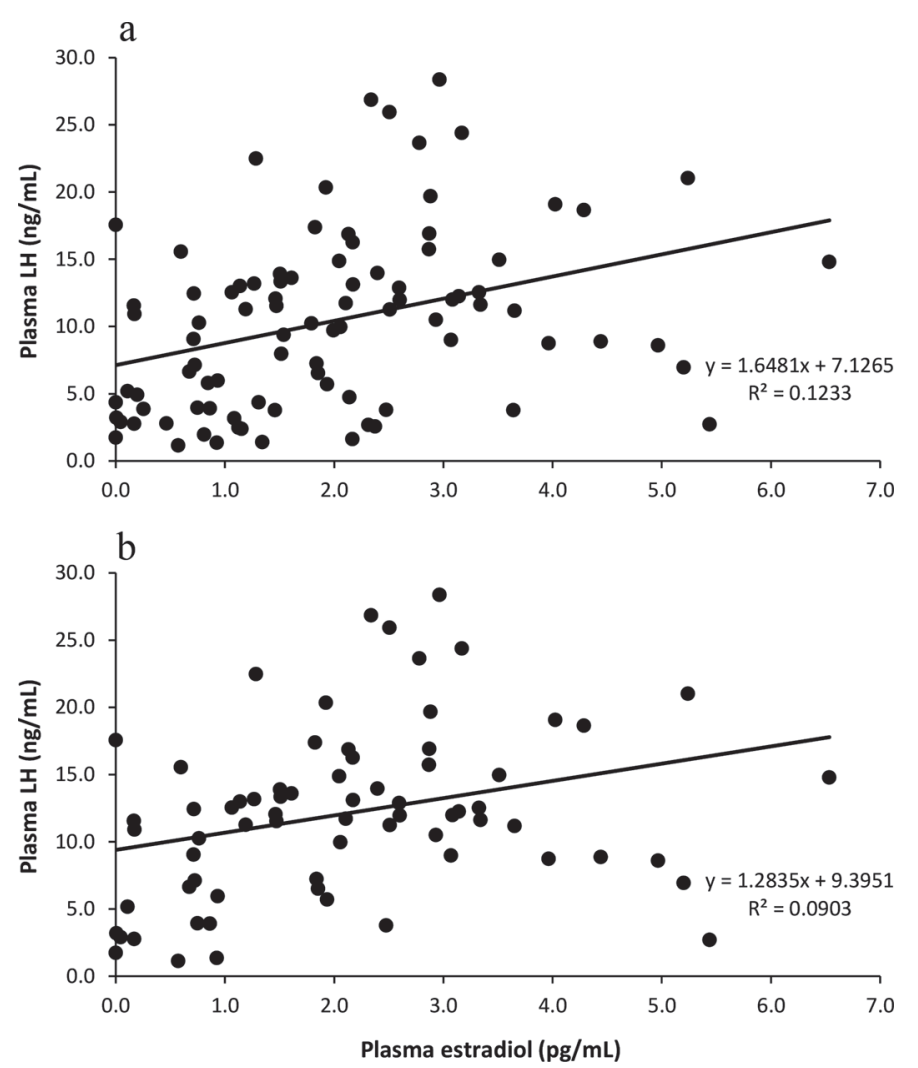

Figure 5. Association between plasma estradiol $(\mathrm{pg} / \mathrm{mL})$ determined at $0 \mathrm{~h}$ before the second $\mathrm{GnRH}$ of Ovsynch and plasma LH (ng/ $\mathrm{mL}$ ) determined at $2 \mathrm{~h}$ after the second $\mathrm{GnRH}$ of Ovsynch in all cows $(\mathrm{a} ; \mathrm{n}=91 ; P<0.01)$ and in cows that had progesterone $(\mathrm{P} 4)<0.5$ $\mathrm{ng} / \mathrm{mL}$ at the second GnRH of Ovsynch (b; $\mathrm{n}=70 ; P<0.01)$.

nonsignificant repeatability estimates (0.10 to 0.20$)$ for LH release when prepubertal ram and ewe lambs $(\mathrm{n}=$ 15 per sex) were repeatedly challenged with exogenous GnRH treatments for 7 consecutive months starting from approximately 9 wk of age. Similarly, Fajersson et al. (1999) reported a nonsignificant range of correlation $(\mathrm{r}=-0.21$ to $0.50 ; P>0.10)$ when beef cattle $(\mathrm{n}=18)$ exhibiting phenotypically extreme LH responses (high and low; selected based on $>1$ SD above the mean and $>1$ SD below the mean, respectively) were subjected to exogenous GnRH injections (100 $\mu$ g i.v.) at d 5 to 8 postpartum (after 2 consecutive calving events) and at $170 \mathrm{~d}$ of gestation. At these 2 distinct time points, cows would have had extreme differences in both energy status and circulating $\mathrm{P} 4$ concentrations. In the present study, we expected a greater repeatability for GnRHinduced LH responses by assessing cows at 8 and $10 \mathrm{wk}$ postpartum (assuming relatively similar energy states) and by eliminating the negative effect of circulating $\mathrm{P} 4$, but repeatability was further reduced (0.10). The GnRH-induced LH response and its repeatability could be negatively influenced by other factors such as low energy intake (Beal at al., 1978) and dietary long-chain fatty acids (Salehi et al., 2015) in addition to negative energy balance during the early postpartum period (Leers-Sucheta at al., 1994). In the current study, possible influences of energy status, high $\mathrm{P} 4$ concentrations, and dietary fats on GnRH-induced LH responses were controlled, avoided, or both by evaluating GnRHinduced LH responses twice within a short interval (8 and $10 \mathrm{wk}$ ), by eliminating cows that had $\mathrm{P} 4 \geq 0.5$ $\mathrm{ng} / \mathrm{mL}$ at $\mathrm{GnRH}$, and by feeding similar diets. Indeed, the overall mean concentrations of $\mathrm{GnRH}$-induced LH did not differ between GnRH of presynchronization and the second GnRH of Ovsynch assessments in the present study. Together, these results suggest that GnRH-induced LH responses have poor repeatability, even under conditions that have been standardized as much as practically possible.

The association between GnRH-induced LH response categories, reproductive hormones, and fertility, under controlled influences of $\mathrm{P} 4(<0.5 \mathrm{ng} / \mathrm{mL})$ has not been previously studied in dairy cows. Cows in the high-LH category had greater concentrations of FSH and a tendency for higher E2 than cows in the low-LH category, and this pattern is evident from the positive associations among LH, FSH, and E2 reported in the current study (Figures 4 and 5) as well as in previous studies (Foster et al., 1980; Nett et al., 2002; Stevenson and Pulley, 2016). We expected that cows with a high LH response to $\mathrm{GnRH}$ treatment would have increased likelihood of ovulation and consequently improved reproductive outcomes compared with cows with a low LH response. However, the reproductive outcomes, such as P/AI at 33 and $60 \mathrm{~d}$ after AI and pregnancy loss, were similar between high- and low-LH categories. Given that this experiment was not adequately powered to evaluate the association between GnRH-induced LH response and fertility outcomes, the results presented herein should be interpreted cautiously. A posteriori power analysis based on the actual difference of $12.5 \%$ in ovulation response called for 93 animals per LH category. With only 24 animals per LH category in the current study, a difference of at least $45 \%$ in ovulatory response was required to attain statistical significance.

In a study conceptually similar to ours, Haley et al. (1989) reported associations between GnRH-induced LH responsiveness and fertility in sheep. They classified ram lambs into high- and low-responsive lines based on mean concentration of $\mathrm{LH}$ determined at $10 \mathrm{wk}$ of age following an i.v. injection of $5 \mu \mathrm{g}$ of $\mathrm{GnRH}$. Thereafter, rams that were classified into high- and low-responsive lines were mated to ewes from the same lines, and progressively bred in a similar manner for several generations. After 8 male generations, the mean LH response for rams in the high-responsive line was 5 times greater 
Table 1. Associations among LH categories, parity, plasma LH, FSH, estradiol, progesterone, and reproductive outcomes in lactating dairy cows

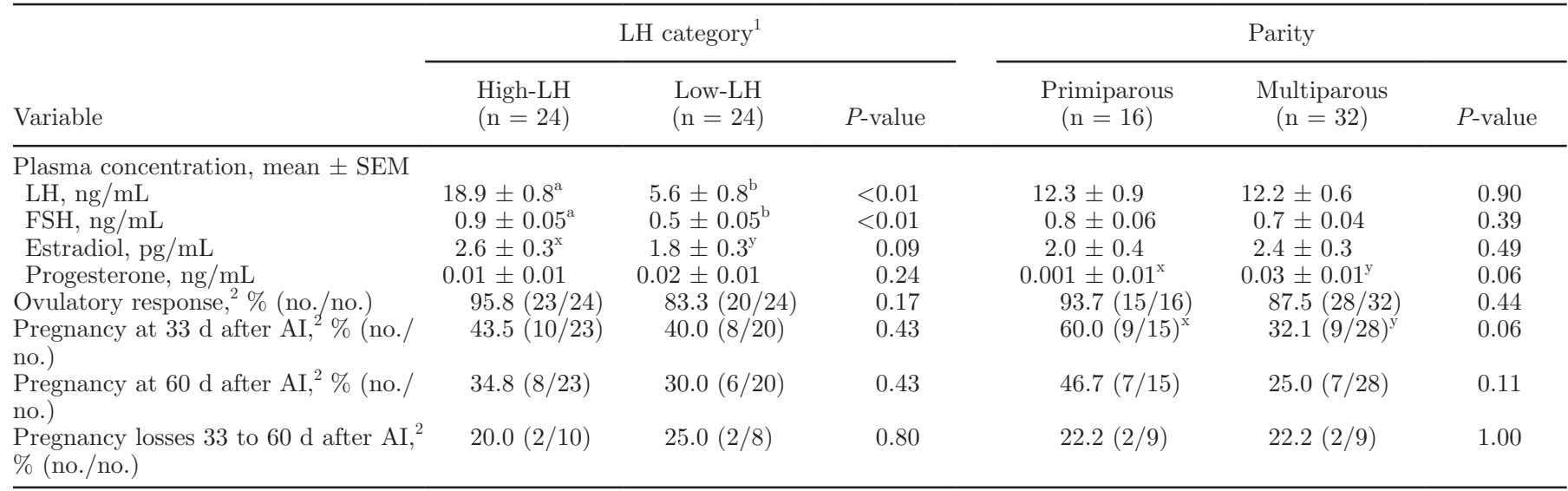

$\overline{\mathrm{a}, \mathrm{b}}$ Different superscripts within the same row and category differ $(P<0.05)$.

${ }^{\mathrm{x}, \mathrm{y}}$ Different superscripts within the same row and category have a tendency to differ $(0.05<P \leq 0.10)$.

${ }^{1} \mathrm{LH}$ categories: cows that had progesterone $<0.5 \mathrm{ng} / \mathrm{mL}$ at the second $\mathrm{GnRH}$ of Ovsynch $(\mathrm{n}=70)$ were ranked by LH concentration, from highest to lowest, and those in the top and bottom thirds were designated as high- and low-LH categories $(\mathrm{n}=24$ each).

${ }^{2}$ Percentages reported for pregnancy at 33 and $60 \mathrm{~d}$ after AI and pregnancy losses between 33 and $60 \mathrm{~d}$ after AI were based on cows that ovulated.
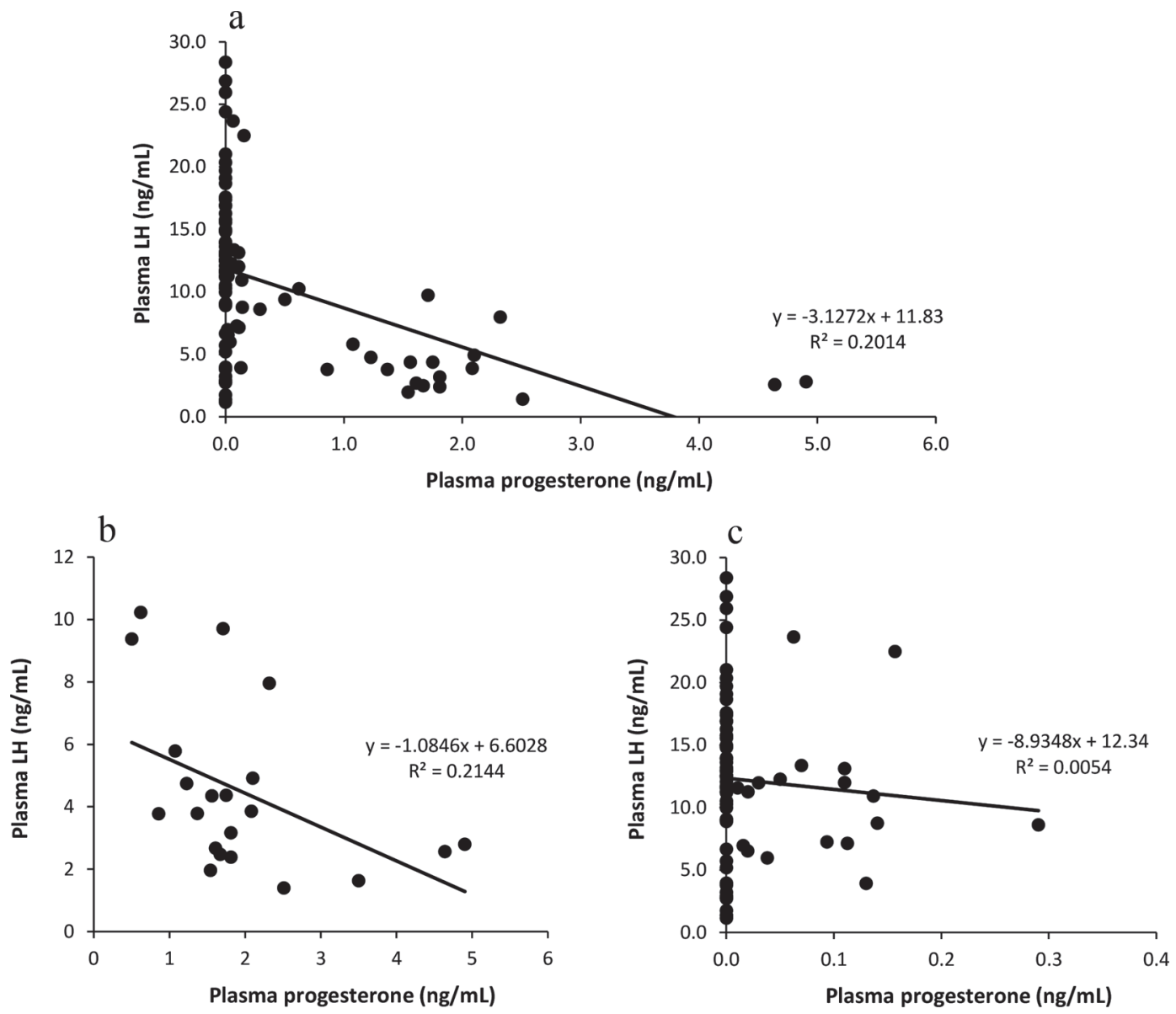

Figure 6. Association between plasma progesterone $(\mathrm{ng} / \mathrm{mL})$ determined before $(0 \mathrm{~h})$ the second $\mathrm{GnRH}$ of Ovsynch and plasma LH (ng/mL) determined at $2 \mathrm{~h}$ after the second GnRH of Ovsynch in all cows $(\mathrm{a} ; \mathrm{n}=91 ; P<0.01)$, in cows that had progesterone $(\mathrm{P} 4) \geq 0.5 \mathrm{ng} / \mathrm{mL}(\mathrm{b} ; \mathrm{n}$ $=21 ; P=0.03)$ and $\mathrm{P} 4<0.5 \mathrm{ng} / \mathrm{mL}(\mathrm{c} ; \mathrm{n}=70 ; P=0.54)$. 
than that of the low-responsive line (Haley et al., 1989). However, the associations between LH responsive lines and fertility were inconsistent. Ewes bred to high responder rams had higher ovulation rates in general than the low-responsive line during the first breeding season but not during the second breeding season. However, increases in the number of lambs born per ewe were not significant except during one generation.

In conclusion, despite high variability, the use of GnRH-induced LH response as a fertility phenotype for genetic selection remains questionable because of its poor repeatability. The association between GnRHinduced LH responses and fertility outcomes under minimal influences of $\mathrm{P} 4$ warrants further investigation in a larger population of dairy cows.

\section{ACKNOWLEDGMENTS}

This project was financially supported in part by Growing Forward 2, a federal-provincial-territorial initiative (Research Opportunities and InnovationInternal Initiatives Project \# DA7642064). M. Gobikrushanth is a recipient of the Teagasc-University of Alberta Walsh Fellowship. The authors thank Courtney Felton, Ana Ruiz-Sanchez, Rohanna Wang, and Ashley L'Hirondelle (University of Alberta) for their assistance during the study and the staff of the Dairy Research and Technology Centre, University of Alberta, for their cooperation and animal care.

\section{REFERENCES}

Adams, G. P., R. L. Matteri, J. P. Kastelic, J. C. H. Ko, and O. J. Ginther. 1992. Association between surges of follicle stimulating hormone and the emergence of follicular waves in heifers. J. Reprod. Fertil. 94:177-188.

Ambrose, J. D., J. P. Kastelic, R. Rajamahendran, M. Aali, and N. Dinn. 2005. Progesterone (CIDR)-based timed AI protocols using $\mathrm{GnRH}$, porcine LH or estradiol cypionate for dairy heifers: Ovarian and endocrine responses and pregnancy rates. Theriogenology 64:1457-1474

Beal, W. E., R. E. Short, R. B. Staigmiller, R. A. Bellows, C. C. Kaltenbach, and T. G. Dunn. 1978. Influence of dietary energy intake on bovine pituitary and luteal function. J. Anim. Sci. 46:181-188.

Burns, D. S., F. Jimenez-Krassel, J. L. Ireland, P. G. Knight, and J. J. Ireland. 2005. Numbers of antral follicles during follicular waves in cattle: Evidence for high variation among animals, very high repeatability in individuals, and an inverse association with serum follicle-stimulating hormone concentrations. Biol. Reprod. $73: 54-62$.

Canadian Council on Animal Care. 2009. CCAC guidelines on the care and use of farm animals in research, teaching and testing. http:// ccac.ca/Documents/Standards/Guidelines/Farm_Animals.pdf.

Colazo, M. G., J. P. Kastelic, H. Davis, M. D. Rutledge, M. F. Martinez, J. A. Small, and R. J. Mapletoft. 2008. Effects of plasma progesterone concentrations on LH release and ovulation in beef cattle given GnRH. Domest. Anim. Endocrinol. 34:109-117.

Colazo, M. G., I. Lopez-Helgurea, A. Behrouzi, D. J. Ambrose, and R. J. Mapletoft. 2017. Relationship between circulating progesterone and fertility in dairy cows subjected to GnRH-based protocols. Theriogenology 94:15-20.

Colazo, M. G., T. O. Ree, D. G. V. Emmanuel, and D. J. Ambrose. 2009. Plasma luteinizing hormone concentrations in cows given repeated treatments or three different doses of gonadotropin releasing hormone. Theriogenology 71:984-992.

Dias, F. C. F., M. G. Colazo, J. P. Kastelic, R. J. Mapletoft, G. P. Adams, and J. Singh. 2010. Progesterone concentration, estradiol pretreatment, and dose of gonadotropin-releasing hormone affect gonadotropin-releasing hormone-mediated luteinizing hormone release in beef heifers. Domest. Anim. Endocrinol. 39:155-162.

Evans, A. C. O., G. P. Adams, and N. C. Rawlings. 1994. Endocrine and ovarian follicular changes leading up to the first ovulation in prepubertal heifers. J. Reprod. Fertil. 100:187-194.

Fajersson, P., R. L. Stanko, and G. L. Williams. 1999. Distribution and repeatability of anterior pituitary responses to $\mathrm{GnRH}$ and relationship of response classification to the postpartum anovulatory interval of beef cows. J. Anim. Sci. 77:3043-3049.

Fink, G. 1988. Gonadotropin secretion and its control. Pages 13491377 in The Physiology of Reproduction. E. Knobil and J. D. Neill, ed. Raven Press, New York, NY.

Foster, J. P., G. E. Lamming, and A. R. Peters. 1980. Short-term relationships between plasma LH, FSH and progesterone concentrations in post-partum dairy cows and the effect of GnRH injection. J. Reprod. Fertil. 59:321-327.

Ginther, O. J. 2000. Selection of the dominant follicle in cattle and horses. Anim. Reprod. Sci. 60-61:61-79.

Giordano, J. O., P. M. Fricke, J. N. Guenther, G. Lopes Jr., M. M. Herlihy, A. B. Nascimento, and M. C. Wiltbank. 2012. Effect of progesterone on magnitude of the luteinizing hormone surge induced by two different doses of gonadotropin-releasing hormone in lactating dairy cows. J. Dairy Sci. 95:3781-3793.

Gobikrushanth, M., P. A. Dutra, T. C. Bruinje, M. G. Colazo, S. T. Butler, and D. J. Ambrose. 2017. Repeatability of antral follicle counts and anti-Müllerian hormone and their associations determined at an unknown stage of follicular growth and an expected day of follicular wave emergence in dairy cows. Theriogenology 92:90-94.

Goodman, R. L., and F. J. Karsch. 1980. Pulsatile secretion of luteinizing hormone: Differential suppression by ovarian steroids. Endocrinology 107:1286-1290.

Haley, C. S., G. J. Lee, M. Fordyce, G. Baxter, R. B. Land, and R. Webb. 1989. Study of LH response to GnRH in the young male as a criterion of genetic merit for female reproduction in sheep. J. Reprod. Fertil. 86:119-133.

Hyttel, P., T. Greve, and H. Callesen. 1989. Ultrastructural aspects of oocyte maturation and fertilization in cattle. J. Reprod. Fertil. Suppl. 38:35-47.

Ireland, J. L. H., D. Sheetz, F. Jimenez-Krassel, A. P. N. Themmen, F. Ward, P. Lonergan, G. W. Smith, G. I. Perez, A. C. O. Evans, and J. J. Ireland. 2008. Antral follicle count reliably predicts number of morphologically healthy oocytes and follicles in ovaries of young adult cattle. Biol. Reprod. 79:1219-1225.

Kaltenbach, C. C., T. G. Dunn, T. E. Kiser, L. R. Corah, A. M. Akbar, and G. D. Niswender. 1974. Release of FSH and LH in beef heifers by synthetic gonadotropin releasing hormone. J. Anim. Sci. $38: 357-362$

Karsch, F. J. 1987. Central actions of ovarian steroids in the feedback regulation of pulsatile secretion of luteinizing hormone. Annu. Rev. Physiol. 49:365-382.

Land, R. B. 1973. The expression of female sex-linked characteristics in the male. Nature 241:208-209.

Leers-Sucheta, S., P. K. Chakraborty, K. E. Rowe, H. A. Turner, and F. Stormshak. 1994. Gonadotropin-releasing hormone-induced release of luteinizing hormone in postpartum beef heifers maintained on two planes of nutrition before and after breeding. J. Anim. Sci. 72:998-1003.

Mossa, F., S. W. Walsh, S. T. Butler, D. P. Berry, F. Carter, P. Lonergan, G. W. Smith, J. J. Ireland, and A. C. O. Evans. 2012. Low number of ovarian follicles $\geq 3 \mathrm{~mm}$ in diameter are associated with low fertility in dairy cows. J. Dairy Sci. 95:2355-2361. 
NRC. 2001. Nutrient Requirements of Dairy Cattle. 7th ed. Natl. Acad. Press, Washington, DC.

Nett, T. M., A. M. Turzillo, M. Baratta, and L. A. Rispoli. 2002. Pituitary effects of steroid hormones on secretion of follicle-stimulating hormone and luteinizing hormone. Domest. Anim. Endocrinol. $23: 33-42$.

Pulley, S. L., D. H. Keisler, and J. S. Stevenson. 2015. Concentrations of luteinizing hormone and ovulatory responses in dairy cows before timed artificial insemination. J. Dairy Sci. 98:6188-6201.

Rawlings, N. C., I. A. Jeffcoate, and D. L. Rieger. 1984. The influence of estradiol-17 $\beta$ and progesterone on peripheral serum concentrations of luteinizing hormone and follicle stimulating hormone in the ovariectomized ewe. Theriogenology 22:473-488.

Ribeiro, E. S., R. S. Bisinotto, F. S. Lima, L. F. Greco, A. Morrison, A. Kumar, W. W. Thatcher, and J. E. P. Santos. 2014. Plasma anti-Müllerian hormone in adult dairy cows and associations with fertility. J. Dairy Sci. 97:6888-6900.

Salehi, R., M. G. Colazo, M. Oba, and D. J. Ambrose. 2015. A prepartum diet supplemented with oilseeds high in oleic or linoleic acid reduced GnRH-induced LH release in dairy cows during second week postpartum. Reprod. Biol. Endocrinol. 13:69.

Schoenemann, H. M., W. D. Humphrey, M. E. Crowder, T. M. Nett, and J. J. Reeves. 1985. Pituitary luteinizing hormone-releasing hormone receptors in ovariectomized cows after challenge with ovarian steroids. Biol. Reprod. 32:574-583.

Spencer, T. E., R. C. Burghardt, G. A. Johnson, and F. W. Bazer. 2004. Conceptus signals for establishment and maintenance of pregnancy. Anim. Reprod. Sci. 82-83:537-550.
Stevenson, J. S., and S. L. Pulley. 2016. Feedback effects of estradiol and progesterone on ovulation and fertility of dairy cows after gonadotropin-releasing hormone-induced release of luteinizing hormone. J. Dairy Sci. 99:3003-3015.

Tomac, T., D. Cekinovic, and J. Arapovic. 2011. Biology of the corpus luteum. Period. Biol. 113:43-49.

Tyrrell, R. N., B. G. Starr, B. J. Restall, and J. B. Donnelly. 1980. Repeatability of $\mathrm{LH}$ responses by lambs to monthly challenge with synthetic GnRH. Anim. Reprod. Sci. 3:155-160.

Webb, R., G. E. Lamming, N. B. Haynes, H. D. Hafs, and J. G. Manns. 1977. Response of cyclic and postpartum suckled cows to injections of synthetic LH-RH. J. Reprod. Fertil. 50:203-210.

Williams, G. L., J. Kotwica, W. D. Slanger, D. K. Olson, J. E. Tilton, and L. J. Johnson. 1982. Effect of suckling on pituitary responsiveness to gonadotropin-releasing hormone throughout the early postpartum period of beef cows. J. Anim. Sci. 54:594-602.

Williams, G. L., and R. L. Stanko. 1996. Variation in anterior pituitary responsiveness to $\mathrm{GnRH}$ in cattle: Potential as a physiological indicator of reproductive merit. J. Anim. Sci. 74(Suppl. 1):214. (Abstr.).

Wilsdorf, L. J., D. H. Keisler, S. E. Poock, W. R. Lamberson, R. C. Escalante, and M. C. Lucy. 2016. Test for nonpregnancy in dairy cows based on plasma progesterone concentrations before and after timed artificial insemination. J. Dairy Sci. 99:5858-5865. 